\section{'Bluebyrd' Plum}

\section{Ralph Scorza and Harold W. Fogle \\ U.S. Department of Agriculture, Agricultural Research Service, Appalachian Fruit Research Station, 45 Wiltshire Road, Kearneysville, WV 25430}

Additional index words. European plum, plum breeding, prune, Prunus domestica

European plums (Prunus domestica L.) offer growers in the eastern United States a fruit crop to add diversity to their line of produce, whether for shipment to city markets or for local and roadside market sales. European plums can also be a welcome addition to the home fruit garden. 'Bluebyrd' plum was developed and released to provide a high quality, consistently highly productive Europeantype plum for the mid-Atlantic region of the United States.

\section{Origin}

'Bluebyrd', tested as B69158, was selected in 1968 by H.W. Fogle at the U.S. Dept. of Agriculture-Agricultural Research Service (USDA-ARS), Agricultural Research Center, Beltsville, Md. It was an open-pollinated seedling of NY H4, a selection of unknown parentage from the New York Agricultural Experiment Station, Geneva, N.Y. 'Bluebyrd' was initially tested in Beltsville, Md. It has been extensively tested in Kearneysville, W.Va., and has also been tested in Geneva, N.Y.; Byron, Ga.; Frederick, Md.; and at several locations in Germany.

\section{Description}

'Bluebyrd' ripens $\approx 10 \mathrm{~d}$ before 'Stanley' plum, generally during the first week of September in Kearneysville, W.Va. Fruit average $51 \mathrm{~mm}$ in length $\times 42 \mathrm{~mm}$ in diameter, weigh between 40 and $50 \mathrm{~g}$, depending on the crop load, and average $20^{\circ}$ Brix $(\approx 20 \%$ soluble solids) (Table 1). The flesh is firm, amber in color, sweet, with a sugar-acid balance that is pleasant to the palate. The skin is deep purple with a wax bloom (Fig. 1). The stone clings slightly to the flesh. Trees of 'Bluebyrd' have an erect growth habit and produce fruit on spurs. 'Bluebyrd' blooms several days before 'Stanley' in most years and produces consistently heavy crops that may require some fruit thinning in years of particularly heavy fruit set to maintain maximum fruit size and to reduce stress on limbs.

\footnotetext{
Received for publication 11 Dec. 1998. Accepted for publication 14 Apr. 1999. We thank W. Hartmann, Universität Hohenheim, Stuttgart, Germany, for providing data on evaluations of 'Bluebyrd' and L. Gilreath and M. Demuth for technical assistance. The cost of publishing this paper was defrayed in part by the payment of page charges. Under postal regulations, this paper therefore must be hereby marked advertisement solely to indicate this fact.
}

'Bluebyrd' is a self-incompatible cultivar and requires a pollinator for fruit set. Under controlled conditions, pollen from 'Stanley' and 'Reine Claude' applied to 'Bluebyrd' produced good fruit set (data not shown). In a at Kearneysville, W.Va. ${ }^{z}$ matured $\approx 7-10 \mathrm{~d}$ later than 'Bluebyrd' fruit. multiple range test, $P \leq 0.01$.

Fig. 1. 'Bluebyrd' plum. mixed planting with 'Stanley', 'Reine Claude', 'Blue Ribbon', 'Bluefre', and unnamed selections, 'Bluebyrd' has produced consistently heavy crops.

Trees of 'Bluebyrd' have survived when exposed to the winter conditions in Kearneysville, W.Va., and Geneva, N.Y. Field observations of 'Bluebyrd' indicate that its resistance to brown rot [Monilinia fructicola (Wint.) Honey] is similar to that of 'Stanley'. It has performed well in tests in Germany (Table 2) but is not resistant to plum pox (Sharka) virus (unpublished). While trees of 'Bluebyrd' have survived and produced fruit in Byron, Ga. (J. Thompson, personal communication), it is not recommended for commercial cultivation in lower chilling areas of the

Table 1. Four-year comparison of 'Bluebyrd' and 'Stanley' fruit size and ${ }^{\circ}$ Brix

\begin{tabular}{lcccc}
\hline Cultivar & Year & Diam $(\mathrm{mm})$ & Length $(\mathrm{mm})$ & ${ }^{\circ}$ Brix \\
\hline Bluebyrd & 1987 & $37 \mathrm{a}^{\mathrm{y}}$ & $46 \mathrm{a}$ & --- \\
Stanley & & $32 \mathrm{~b}$ & $43 \mathrm{~b}$ & -- \\
Bluebyrd & 1988 & $40 \mathrm{a}$ & $53 \mathrm{a}$ & --- \\
Stanley & & $39 \mathrm{a}$ & $49 \mathrm{~b}$ & --- \\
Bluebyrd & 1994 & $47 \mathrm{a}$ & $57 \mathrm{a}$ & $20.4 \mathrm{a}$ \\
Stanley & & $42 \mathrm{~b}$ & $56 \mathrm{a}$ & $14.8 \mathrm{~b}$ \\
Bluebyrd & 1998 & $42 \mathrm{a}$ & $46 \mathrm{~b}$ & $22.9 \mathrm{a}$ \\
Stanley & & $40 \mathrm{~b}$ & $55 \mathrm{a}$ & $16.6 \mathrm{~b}$ \\
\hline
\end{tabular}

${ }^{\mathrm{z}}$ Samples of 25 fruit per tree randomly collected from one tree per cultivar per year, except in 1994 when 10 fruit per tree were sampled. 'Stanley' fruit

${ }^{y}$ Mean separation within columns and years by ANOVA-CRD and Duncan's

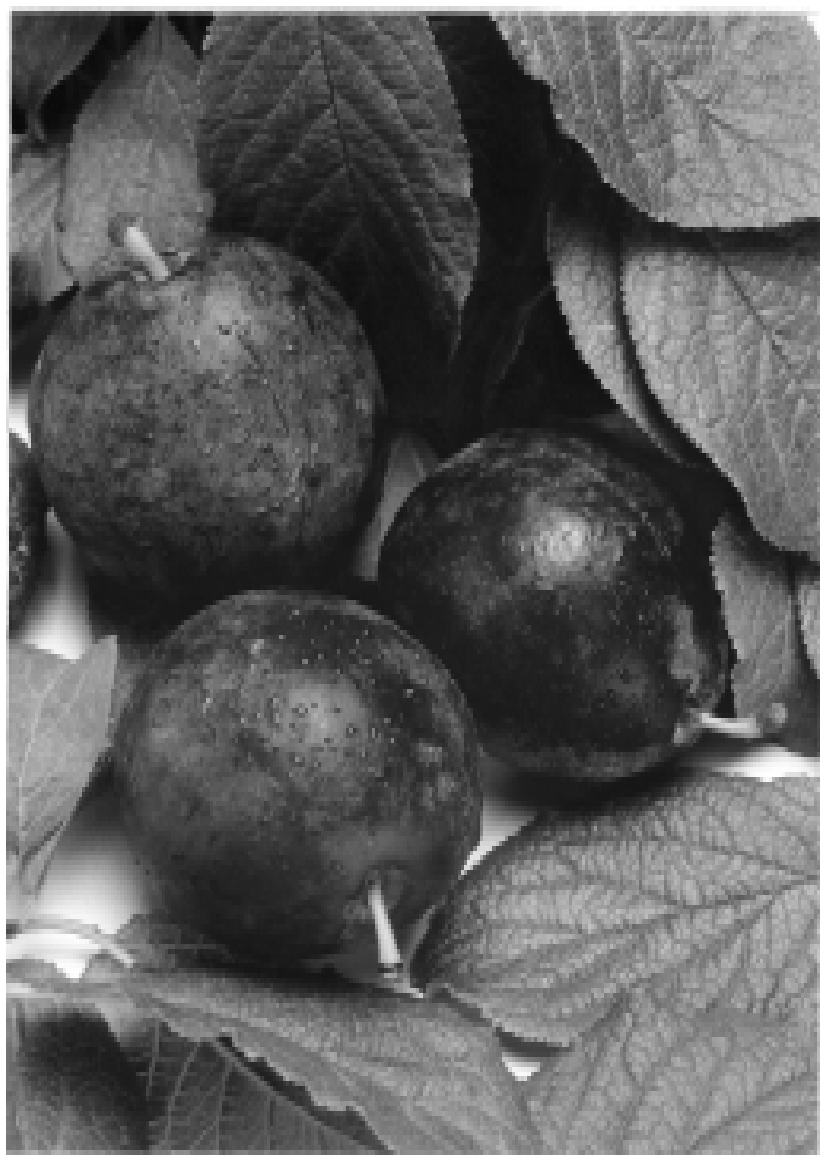


Table 2. Evaluations of 'Bluebyrd' plum at three locations. Fruit weight and ${ }^{\circ}$ Brix based on samples of 20-35 fruit except where otherwise noted.

\begin{tabular}{lcccc}
\hline \hline Year & Ripe date & Wt $(\mathrm{g})$ & Yield rating $^{\mathrm{z}}$ & ${ }^{\circ}$ Brix \\
\hline \multicolumn{5}{c}{ Ortenburg, Germany } \\
1994 & 1 Sept. & 51 & $\mathrm{H}^{\mathrm{y}}$ & \\
1996 & 3 Sept. & 47 & $7 / 9^{\mathrm{y}}$ & 15.6 \\
& & Hohenheim, Germany & & \\
1996 & 9 Sept. & 52 & $3 / 9^{\mathrm{y}}$ & 20.2 \\
& & Kearneysville, W.Va. & & \\
1989 & 31 Aug. & --- & $8 / 9^{\mathrm{y}}$ & 22.0 \\
$1993^{\mathrm{x}}$ & 27 Sept. & 40 & $8 / 9^{\mathrm{y}}$ & 19.8 \\
$1994^{\mathrm{x}}$ & 29 Aug. & --- & -- & 20.4 \\
$1997^{\mathrm{w}}$ & 30 Aug. & 39 & $7 / 9^{\mathrm{v}}$ & --- \\
$1997^{\mathrm{w}}$ & 30 Aug. & 35 & $9 / 9^{\mathrm{y}}$ & -- \\
1998 & 2 Sept. & 47 & $8 / 9^{\mathrm{v}}$ & 22.9 \\
\hline
\end{tabular}

${ }^{2}$ Ratings based on a 0 to 9 scale; $0=$ no crop, $9=$ heavy load causing extreme branch bending, and occasionally, branch breakage. On 1 Sept. 1994 in Ortenburg, Germany, a different rating was used with $\mathrm{H}=$ heavy fruit load.

${ }^{y}$ Nonthinned tree.

${ }^{\mathrm{x}}$ Ten fruit sampled for size and ${ }^{\circ} \mathrm{Brix}$

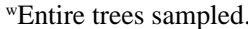

${ }^{v}$ Fruit commercially thinned. southern states because the chilling requirement for normal bloom may not be fulfilled in all years in these areas.

\section{Availability}

'Bluebyrd' has been released as a public cultivar. There are no restrictions on its propagation. 'Bluebyrd' has been extensively tested for the presence of virus and virus-like diseases by the National Research Support Program 5 for virus testing and therapy of deciduous fruit trees. All tests have been negative, indicating that 'Bluebyrd' is virus-free. Budwood of 'Bluebyrd' will be available in Summer 2000 from the National Research Support Program 5, Washington State Univ., Prosser, WA 99350. Currently, limited amounts of budwood are available from the senior author at the USDA-ARS Appalachian Fruit Research Station. 